\title{
PERAN SERTA LEMBAGA PENDIDIKAN TINGGI DI KOTA SEMARANG DALAM MENDORONG PERTUMBUHAN PERBANKAN SYARI'AH DI KOTA SEMARANG
}

\author{
Suwanto \\ Dosen Institut Agama Islam Negeri (IAIN) Walisongo Semarang \\ mazwanto@ymail.com
}

\begin{abstract}
The purpose of this research is intended to determine the role of the IAIN Walisongo Semarang in encouraging the growth of sharia banking in Semarang. A descriptive qualitative method is applied in order to obtain data in this study through collecting and analyzing the related literature to this research. Moreover observation, interviews and secondary data on the development of Islamic banking from sharia banking statistic Indonesian Banking are caried out.

The finding shows that the IAIN Walisongo Semarang has a role in encouraging the growth of sharia banking in Semarang through the development discourse and discipline of Islamic economics to open a graduate studies program of applied science of Islamic banking, the establishment of Islamic financial institutions BMT Walisongo, cases and the concept of derivation Development Sharia Banking, Products and Services, Socialization, and Human Resource Competencies, Roles in providing competence buman resources on Islamic banking, Development and Assistance to financing customers, dissemination of Islamic banking in the community, cooperation with agency of Sharia Financing, involvement of State Polytechnic of Semarang in Islamic banking in financing, and Encouraging society become customer of Islamic Banking.

Finally the bigher education institutions in Indonesia bave an opportunity to meet the needs of Islamic banking industry through the activities of Tri Darma Perguruan Tinggi, especially to belp the business sectors to alleviate the problems derivation and translation of national rules of Islamic Banking, products and services, socialization, and buman resource competencies.
\end{abstract}

Keywords: Sharia Banking, Growth, Islamic Economics, Islamic Financial Institutions, and Islamic Human Resources 


\begin{abstract}
Abstrak
Penelitian ini bertujuan mengetabui bagaimana IAIN Walisongo Semarang sebagai lembaga pendidikan berperan serta dan tanggung jawab dalam pengembangan ekonomi syari'ah. IAIN Walisongo diharapkan mampu menjadi sumber pengembangan dan sosialisasi perbankan syariah untuk mendorong pertumbuban perbankan syari'ah di Kota Semarang.

IAIN Walisongo Semarang telah berperan serta dalam mendorong pertumbuban perbankan syari'ab di Kota Semarang melalui pengembangan wacana dan disiplin keilmuan ekonomi Islam melalui dibukanya program studi sarjana sains terapan perbankan syari'ah, pembentukan lembaga keuangan syari'ah BMT Walisongo, sosialisasi, dan kompetensi sumber daya manusia yang kompeten, serta, pembinaan dan pendampingan terhadap nasabah pembiyaan.

Adapun metode yang digunakan adalab metode deskriptif kuantitatif. Untuk memperoleb bahan data dalam penelitian ini, dilakukan wawancara, observasi, serta mengumpulkan dan menganalisis pustaka yang berbubungan dengan penelitian.

Dari hasil penelitian dapat dirumuskan rekomendasi babwa lembagalembaga pendidikan tinggi di Indonesia, dalam bal ini IAIN Walisongo Semarang memiliki peluang besar untuk mengisi kebutuban industri perbankan syari'ab nasional melalui kegiatan Tri Darma Perguruan Tinggi, terutama mengentaskan masalab-masalab derivasi dan translasi aturan perbankan syari'ah nasional, sosialisasi, dan kompetensi sumber daya insani.
\end{abstract}

Kata kunci: Perbankan Syari'ah, Pertumbuhan, Peran, Ekonomi Islam, Lembaga Keuangan Syari'ah, Sumber Daya Insani.

\title{
Pendahuluan
}

Bank Syari'ah muncul di Indonesia sekitar tahun 90-an atau tepatnya setelah keberadaan UU No. 7 Tahun 1992 direvisi dengan UU No. 10 Tahun 1998 dalam bentuk bank yang beroperasi dengan sistem bagi hasil (Antonio, 2001). Dalam Undang-Undang tersebut diatur dengan rinci landasan hukum serta jenis-jenis usaha yang dapat dioperasikan dan diimplementasikan oleh Bank Syari'ah.

Eskalasi pertumbuhan bank syari'ah tidak hanya dipengaruhi political will pemerintah dengan diterbitkannya UU No. 10 tahun 
1998, tetapi juga dipengaruhi oleh sosialisasi dan propaganda bank syari'ah oleh umat Islam yang terus meningkat, baik oleh kalangan praktisi, ulama, maupun oleh lembaga pendidikan (Hilman, 2003). Mengingat semakin pesatnya pertumbuhan beberapa institusi ekonomi berbasis syari'ah sangat menggembirakan, akan tetapi penyediaan dan pembinaan sumber daya manusia yang memadai di bidang ekonomi syari'a masih sangat terbatas. Oleh karenanya perlu langkah strategis dan riil di antaranya adalah menyediakan fasilitas pendidikan berbasis syari'ah untuk menyediakan sumber daya manusia yang berkualitas, beriman dan bertaqwa. Untuk itu beberapa perguruan tinggi membuka jurusan Ekonomi Islam, Perbankan Syari'ah seperti IAIN Walisongo.

Dibukanya konsentrasi Ekonomi Islam dan Program Studi Perbankan Syari'ah IAIN Walisongo berfungsi dalam menunjukkan peran serta Program Studi Perbankan Syari'ah IAIN Walisongo sebagai lembaga pendidikan dalam merespon perkembangan perbankan syari'ah yang semakin marak di Kota Semarang. Ada banyak hal yang bisa diharapkan dari peran lembaga pendidikan dalam pengembangan ekonomi syari'ah, antara lain: Pertama, masyarakat akan menyadari bahwa bidang ekonomi dalam Islam benar-benar menjadi bagian dari Islam itu sendiri. Kedua, masih dimilikinya pandangan positif, bahwa masyarakat akan menghormati dan menjalankan ajaran-ajaran Islam tentang ekonomi syari'ah.

Dari hasil pengamatan di lapangan, respon IAIN Walisongo sebagai lembaga pendidikan terhadap perkembangan perbankan syari'ah di Kota Semarang yaitu membuka program studi Perbankan Syari'ah, akan tetapi belum diikuti dengan pemakaian produk dan jasa perbankan syari'ah secara menyeluruh. Hal ini dapat terlihat dengan masih dipergunakannya produk dan jasa perbankan konvensional dalam transaksi pembayaran SPP di Program Studi Perbankan Syari'ah IAIN Walisongo, di mana SPP merupakan sumber pendapatan kedua terbesar setelah biaya rutin dan biaya pembangunan. Dalam hal ini berarti Program Studi Perbankan Syari'ah IAIN Walisongo baru menjalankan perannya sebagai lembaga pendidikan yang mengenalkan Ekonomi Islam melalui teori dan konsep. Perkembangan perbankan syari'ah cukup signifikan dari tahun ke tahun tidak diikuti dengan perkembangan pangsa pasar perbankan 
syari'ah terhadap total perbankan nasional.

Di Kota Semarang terdapat beberapa lembaga pendidikan tinggi, akan tetapi lembaga pendidikan tinggi yang berbasis Islam sekaligus juga mempunyai konsentrasi program studi Ekonomi Islam ataupun Perbankan Syari'ah hanyalah IAIN Walisongo. Oleh karena itu dalam penelitian ini, peran serta lembaga pendidikan tinggi di Kota Semarang direpresentasikan oleh institusi IAIN Walisongo, sebagai satu-satunya institusi lembaga pendidikan tinggi di Kota Semarang yang ikut mendorong perkembangan dan pertumbuhan perbankan syari'ah di Kota Semarang. Berdasar perspektif di atas, yang menjadi problem akademik adalah bagaimana peran serta Program Studi Perbankan Syari'ah IAIN Walisongo Semarang dalam mendorong perbankan syari'ah di Kota Semarang.

\section{Profile Pengembangan Pasar Perbankan Syari'ah}

Kegiatan pengembangan perbankan syari'ah pada tahun 2009 merupakan kelanjutan implementasi Grand StrategyPengembangan Pasar Perbankan Syari'ah yang telah memasuki Fase II yang dilaksanakan melalui serangkaian program yang terintegrasi yaitu; (i) Program pencitraan baru perbankan syari'ah; (ii) Program pengembangan segmen pasar perbankan syari'ah; (iii) Program pengembangan produk; (iv) Program peningkatan pelayanan; dan (v) Program sosialisasi dan komunikasi terhadap stakeholders yang terkait secara langsung maupun tidak langsung untuk pengembangan pasar.

Pelaksanaan program Grand Strategy tahun 2009 masih diprioritaskan kepada program pencitraan baru, pengembangan segmen pasar yang dikemas dalam program sosialisasi dan komunikasi yang terpadu dan terfokus dengan memperhatikan 5 (lima) segmen nasabah bank syari'ah hasil pemetaan grand strategy yaitu segmen pokoknya syari'ah, segmen ikut-ikutan, segmen sesuai kebutuhan dan manfaat, segmen terpaksa dan segmen pokoknya konvensional yang menjadi acuan dalam melaksanakan sosialisasi dan edukasi tahun 2009. Strategi ini dilakukan untuk meningkatkan awareness masyarakat terhadap perbankan syari'ah sebagai "lebih dari sekedar bank". 
Mendorong Spin off UUS: Mempercepat Pertumbuban Industri dan Menuju Struktur Industriyang Ditopang oleh Bank Syari'ab Full-Fledged

Kebijakan dual system bank yang ditetapkan tahun 1999 setelah berlakunya UU No. 10 Tahun 1998 tentang Perbankan telah memberikan kontribusi besar dalam percepatan pertumbuhan perbankan syari'ah dan meningkatkan awareness dan preferensi masyarakat terhadap perbankan syari'ah. Terutama karena keterlibatan bank-bank umum besar dengan branding kuat dan jaringan kantor luas. Bank-bank konvensional besar tersebut mengembangkan layanan jasa perbankan syari'ah dengan platform kualitas layanan setara dengan layanan produk konvensionalnya. Efisiensi dan perluasan layanan perbankan syari'ah semakin meningkat dengan diperkenankannya konsep layanan office channeling pada Maret 2006. Aturan office channeling merupakan ketentuan yang memperkenankan delivery layanan jasa perbankan syari'ah melalui channel kantor konvensional bank yang sama tanpa harus membuka kantor baru. Dari aspek mitigasi berbagai risiko khususnya risiko reputasi yang dihadapi oleh bank dengan dual system tersebut ditetapkan berbagai berbagai kebijakan yang intinya menciptakan firewalluntuk menghindari ketercampuran antara aset unit konvensional dengan aset unit syari'ah bank, peningkatan peran DPS dan keharusan mengembangkan sistem pembukuan dan pelaporan terpisah.

Pelaksanaan konsep dual banking system walaupun efektif dalam mendorong pertumbuhan perbankan syari'ah namun sekaligus menimbulkan berbagai permasalahan baik yang bersifat teknis operasional perbankan syari'ah maupun dari aspek strategi jangka panjang pengembangan perbankan syari'ah. Oleh karena itu, pengembangan perbankan syari'ah yang bertumpu pada pelaksanaan dual system bank dianggap sebagai kebijakan yang bersifat situational-temporer. Sehingga dalam UU No. 21 Tahun 2008 tentang Perbankan Syari'ah ditetapkan suatu arah kebijakan baru di mana secara bertahap didorong agar bank umum konvensional memisahkan UUS (spin off) menjadi entitas bank umum syari'ah baru.

Terdapat berbagai alternatif model spin-off UUS yang dapat dipilih oleh bank umum konvensional; yaitu; (1) memisahkan UUS bank dan digabungkan ke dalam entitas bank umum syari'ah baru yang merupakan anak perusahaan bank yang sama (BUS baru 
dimaksud dapat merupakan hasil konversi bank umum konvensional yang diakusisi oleh bank induk); (2) memisahkan UUS milik bank induk dengan langsung menjadikan UUS hasil pemisahan sebagai cikal bakal entitas bank umum syari'ah baru; dan (3) memisahkan UUS-UUS milik beberapa bank umum konvensional secara bersamaan dan digabungkan, di mana hasil penggabungan harta dari UUS-UUS tersebut akan dijadikan satu entitas bank umum syari'ah baru. Secara praktik, spin off pola pertama telah dilaksanakan dalam rangka pemisahan UUS Bank BRI dan UUS Bank Bukopin, sedangkan spin off pola kedua akan diterapkan dalam rangka pemisahan UUS Bank BNI dan UUS Bank Jabar Banten. Spin off pola ketiga secara ideal cocok diterapkan bagi UUS bankbank umum konvensional yang memiliki kemampuan terbatas untuk memenuhi batas minimum permodalan yang dapat menjamin sustainability pertumbuhan bank syari'ah baru pasca spin off.

Spin off pola pertama yang memiliki ciri peleburan (merger) dua atau lebih unit usaha bank ke dalam satu entitas bank syari'ah baru tentu menghadapi tantangan yang lebih kompleks dalam mengintegrasikan berbagai aspek seperti kultur dan perilaku kerja, akuntasi penggabungan harta dan kewajiban dan lain-lain. Secara umum hal-hal yang perlu menjadi perhatian dalam semua pola spin off adalah masalah terkait ketenagakerjaan/SDM, kesiapan sistem informasi, masalah risiko hukum dalam peralihan hak dan kewajiban UUS ke dalam bank baru, pengaturan berbagai sharing sumber daya, yang antara lain sistem IT, training center, promosi, dan marketing dengan bank induk.

\section{Prospek Bank Syari'ah}

Perbankan syari'ah mempunyai potensi dan prospek yang sangat bagus untuk dikembangkan di Indonesia. Prospek yang baik ini setidaknya ditandai oleh empat hal. Pertama, Jumlah penduduk Indonesia yang mayoritas beragama Islam merupakan pasar potensial bagi pengembangan bank syari'ah di Indonseia. Sampai saat ini, pangsa pasar yang besar itu belum tergarap secara signifikan. Market share bank syari'ah masih sangat besar.

Kedua, Perkembangan Lembaga Pendidikan Tinggi yang mengajarkan ekonomi syari'ah semakin pesat, baik D3, S1, S2, 
maupun S3. Dalam lima tahun ke depan akan lahir sarjana-sarjana ekonomi Islam yang memiliki paradigma, pengetahuan dan wawasan ekonomi syari'ah yang komprehensif, tidak seperti sekarang, banyak yang masih menolak ekonomi syari'ah karena belum memiliki pengetahuan yang mendalam tentang ekonomi syari'ah.

Ketiga, Bahwa fatwa MUI tentang keharaman bunga bank, bagaimanapun akan tetap berpengaruh terhadap pertumbuhan perbankan syari'ah. Pasca fatwa MUI tersebut, terjadi shifting dana masyarakat dari bank konvensional ke bank syari'ah secara signifikan yang meningkat dari bulan-bulan sebelumnya. Menurut data Bank Indonesia, dalam waktu satu bulan pasca fatwa MUI, dana pihak ketiga yang masuk ke perbankan syari'ah hampir Rp 1 trilyun. Fatwa ini semakin mendapat dukungan dari para sarjana ekonomi Islam.

Keempat, Harapan kita kepada sikap pemerintah cukup besar untuk berpihak pada kebenaran, keadilan dan kemakmuran rakyat. Political will pemerintah untuk mendukung pengembangan perbakan syari'ah di Indonesia tinggal menunggu waktu, lama kelamaan mereka akan sadar juga dan melihat keunggulan bank syari'ah. Sejumlah pemerintah daerah telah mendukung dan bergabung membesarkan bank-bank syari'ah. Memang banyak peran Bank Indonesia dalam mendorong pertumbuhan bank syari'ah, khususnya dalam regulasi, namun kegiatan sosialisasi dan pencerdasan bangsa masih relatif kecil dilaksanakan dan didukung Bank Indonesia.

Kelima, masuknya lembaga-lembaga keuangan internasional ke dalam jasa usaha perbankan syari'ah di Indonesia sesungguhnya merupakan indikator bahwa usaha perbankan syari'ah di Indonesia memang prospektif dan dipercaya oleh para investor luar negeri. Potensi dana Timur Tengah sangat besar. Dana-dana yang selama ini ditempatkan di Amerika dan Eropa, pasca 11 September WTC, mulai ditarik oleh investor Arab untuk ditempatkan di Asia. Ketika harga minyak 32 dollar US per barel, Timur Tengah telah menjadi negara petro dollar, apalagi ketika harganya meningkat menjadi 70 dolar per barel, tentu dana itu semakin besar. Bila potensi ini berhasil ditarik oleh bank-bank syari'ah, maka market share bank-bank syari'ah akan semakin besar. 
Peran Lembaga Pendidikan dalam Mendorong Pertumbuhan Perbankan Syari'ah.

Peran adalah sesuatu yang diharapkan dimiliki oleh yang memiliki kedudukan dalam masyarakat. Peranan ialah proses cara atau perbuatan memahami perilaku yang diharapkan dan dikaitkan dengan kedudukan seseorang. Seseorang dikatakan telah berperan apabila dia telah melaksanakan hak dan kewajibannya sesuai dengan kedudukannya. Adapun cakupan peran Menurut Levinson dalam Soekanto (1982), menyatakan bahwa peran mencakup 3 (tiga) hal, yaitu;

1. Peranan yang meliputi norma-norma yang dihubungkan dengan posisi atau tempat seseorang dalam masyarakat. Peranan dalam arti ini merupakan rangkaian peraturan-peraturan yang membimbing seseorang dalam kehidupan kemasyarakatan.

2. Peranan adalah suatu konsep perihal apa yang dapat dilakukan oleh individu dalam masyarakat sebagai organisasi.

3. Peranan juga dapat dikatakan sebagai perilaku individu yang penting bagi struktur sosial masyarakat.

Banyak hal yang bisa diharapkan dari peran lembaga pendidikan dalam pengembangan ekonomi Syariah, antara lain; Pertama, masyarakat akan menyadari bahwa bidang ekonomi dalam Islam benar-benar menjadi bagian dari Islam itu sendiri; Kedua, masih adanya anggapan yang positif bahwa masyarakat akan menjalankan praktik syari'ah dengan benar terutama tentang ekonomi syari'ah.

Terdapat 2 (dua) peran strategis lembaga pendidikan, yaitu; Pertama, lembaga pendidikan akan mendidik para pelaku, regulator, supervisor yang mengenal baik filosof, teori, konsep maupun praktik ekonomi syari'ah yang benar; Kedua, lembaga pendidikan dapat memberikan arah pengembangan perbankan syari'ah melalui penelitian dan pengembangn teori dan konsep-konsepnya yang akan menyempurnakan praktik perbankan syari'ah.

\section{Peran dan Proses Sosial}

Proses sosial dapat diartikan sebagai hubungan timbal balik antara individu dengan individu, antara individu dengan kelompok, dan antara kelompok dengan kelompok, berdasarkan potensi atau 
kekuatan masing-masing. Salah satu bentuk proses sosialnya yaitu kerja sama (cooperation). Kerja sama adalah suatu bentuk proses sosial di dalamnya terdapat aktivitas tertentu yang ditujukan untuk mencapai tujuan bersama dengan saling membantu dan saling memahami terhadap aktivitas masing-masing.

Dengan dibukanya Program Studi Perbankan Syari'ah pada IAIN Walisongo berarti ikut mengembangkan ekonomi Islam, mendukung kajian ekonomi Islam, membantu sosialisasi perbankan syari'ah. Mahasiswa Program Studi Perbankan Syari'ah yang akan menyelesaikan studi akan mengadakan penelitian tentang ekonomi Islam, nantinya penelitian-penelitian itu bisa disosialisasikan sehingga bisa membantu sosialisasi dan pengembangan ekonomi Islam, sekaligus mahasiswa dipersiapkan untuk menjadi sumberdaya manusia, mengingat masih banyak pegawai yang bekerja di perbankanperbankan syari'ah yang ada di Kota Semarang saat ini masih banyak yang berasal dari sarjana ekonomi konvensional, sehinga mereka perlu pendidikan lagi untuk memahami sistem ekonomi Islam khususnya sistem perbankan syari'ah. Saat ini perbankanperbankan syari'ah yang ada di Kota Semarang mengharapkan sarjana-sarjana ekonomi Islam yang benar-benar berkompeten, agar perbankan syari'ah yang telah ada dapat berkembang lebih baik.

\section{Metodologi Penelitian}

Subjek dalam penelitian ini adalah para pejabat di lingkungan IAIN Walisongo Semarang yang terdiri dari jajaran Rektor, Dekan, Ketua Jurusan, Ketua Lembaga-lembaga di IAIN Walisongo, serta pengelola Program Studi Perbankan Syari'ah IAIN Walisongo. Sedangkan objek dalam penelitian ini ialah bentuk-bentuk peran serta Program Studi Perbankan Syari'ah IAIN Walisongo Semarang dalam mendorong pertumbuhan perbankan syari'ah di Kota Semarang.

Untuk mengumpul data penulis menggunakan beberapa teknik antara lain; Wawancara, yaitu cara bertanya langsung kepada para pejabat terkait di lingkungan IAIN Walisongo Semarang; Observasi, yaitu cara mengumpulkan data yang penulis lakukan dengan mengamati gejala-gejala yang ada di lapangan; dan, riset pustaka, untuk dijadikan landasan teoritis dalam penelitian ini. 
Data yang diperoleh dari lapangan dianalisis setelah dikelompokkan ke dalam kategori-kategori berdasarkan perumusan masalah jenis data tersebut, dengan tujuan dapat menggambarkan permasalahan yang diteliti, kemudian dianalisis dengan menggunakan pendapat atau teori para ahli yang relevan.

\section{Analisis}

\section{Diskripsi Perkembangan Perbankan Syari'ah di Kota Semarang}

Kinerja perbankan di Kota Semarang pada tahun 2009 secara umum mengalami pertumbuhan, walaupun sedikit melambat jika dibandingkan dengan tahun 2008. Lambatnya pertumbuhan tersebut sebagai dampak adanya krisis keuangan global yang mulai terasa pada tahun 2008, yang tercermin dari menurunnya pertumbuhan dana pihak ketiga (DPK) dan kredit yang diberikan. DPK dan kredit masing-masing tumbuh sebesar 13,18\% dan 13,69\%, melambat dibanding pertumbuhan pada 2008 yang masing-masing sebesar $16,20 \%$ dan $27,98 \%$

Perkembangan bank umum syari'ah (BUS) dan BPR syari'ah (BPRS) di Kota Semarang menunjukkan peningkatan, yang tercermin dari pertumbuhan indikator utama kinerja perbankan syari'ah. Dalam empat tahun terakhir, aset bank syari'ah memiliki rata-rata pertumbuhan sebesar 49,98\%. Sedangkan pembiayaan dan DPK BPRS memiliki rata-rata pertumbuhan masing-masing sebesar 49,88 \% dan 43,12 \% (Statistik Ekonomi dan Keuangan Daerah, Bank Indonesia, 2011). Relatif tingginya pertumbuhan indikator kinerja perbankan syari'ah di Kota Semarang tersebut terutama disebabkan adanya perluasan wilayah usaha perbankan syari'ah melalui pembukaan kantor cabang baru di beberapa daerah. Pada tahun 2006 terdapat 26 kantor cabang, meningkat menjadi 43 kantor cabang pada 2009. Peningkatan jumlah kantor tersebut memberikan pengaruh positif pada Financing to Deposit Ratio (FDR) yang mengalami kenaikan hingga mencapai 109,97\%. Peningkatan FDR tersebut juga diimbangi dengan peningkatan kualitas pembiayaan yang disalurkan oleh perbankan syari'ah di Jawa Tengah. Hal ini tercermin dari semakin menurunnya tingkat Non Performing Financing (NPF), di mana pada 2009 NPF Bank Syari'ah tercatat sebesar 2,72 \% (Statistik 
Ekonomi dan Keuangan Daerah, Bank Indonesia, 2010).

Pertumbuhan perbankan syari'ah di wilayah kerja Kantor Bank Indonesia (KBI) Semarang mengalami prestasi melebihi tingkat pertumbuhan perbankan syari'ah nasional. Berdasarkan data KBI Semarang, tingkat pertumbuhan perbankan syari'ah di wilayah kerjanya pada posisi November 2009 dibandingkan bulan Desember 2008 mengalami kenaikan 36,90 persen dengan total aset sebesar Rp 1,885 triliun. Dana pihak ketiga yang berhasil dihimpun dari sistem keuangan berbasis syari'ah ini mencapai Rp 1,195 triliun dan pembiayaan yang telah disalurkan mencapai Rp 1,371 triliun.

Sebagai data pembanding pertumbuhan digunakan posisi November 2009 terhadap posisi Desember 2008. Berdasarkan kriteria tersebut, kategori kantor cabang BUS/UUS dengan asset di atas Rp 100 milyar diraih Bank Syari'ah Mandiri (BSM) Kantor Cabang Semarang. Untuk kategori kantor cabang BUS/UUS dengan asset kurang dari Rp 100 milyar diperoleh Bank CIMB Niaga Syari'ah Kantor Cabang Semarang. Sedangkan untuk kategori Bank Pembiayaan Rakyat Syari'ah (BPRS) diperoleh PT BPRS Artha Surya Barokah, Kota Semarang. Ketiga bank syari'ah tersebut memiliki tingkat pertumbuhan yang melebihi dari rata-rata tingkat pertumbuhan seluruh bank syari'ah di wilayah kerja KBI Semarang.

\section{Urgensi Derivasi Pengembangan Konsep Perbankan Syari'ah}

Pada dasarnya, UU No. 10 Tahun 1998 telah berupaya mengakomodasi kepentingan pengembangan industri ini, namun celah kelemahan perangkat hukum tersebut nampak efektif mereduksi kekuatan pengembangan industri ini ke level yang seharusnya.

Sebagai lembaga ilmiah dan independen, perguruan tinggi dapat berperan efektif untuk menjaga translasi dan derivasi hukum di atas tetap berada dalam koridor syari'ah murni, namun tetap merespon dinamika perubahan yang dihadapi oleh perbankan syari'ah nasional. Melalui kegiatan penelitiannya, lembaga-lembaga pendidikan tinggi dapat menyumbangkan gagasan-gagasan mengenai derivasi dan penyesuaian peraturan-peraturan teknis yang dapat menstimulasi kualitas kompetitif bank-bank syari'ah nasional. Selain itu, kolaborasi penelitian antara lembaga pendidikan tinggi dan industri perbankan syari'ah dapat memberikan penjelasan 
tentang fleksibilitas regulasi yang diperlukan untuk membangun daya saing investasi syari'ah nasional. Lembaga pendidikan tinggi berperan dalam mengakselerasi pertumbuhan industri perbankan syari'ah nasional melalui pengembangan regulasi.

Dalam konteks ini, IAIN Walisongo telah beberapa kali melakukan riset di bidang perbankan syari'ah, dengan mengirimkan penelitian-penelitian ilmiah pada tingkat lokal, regional, bahkan nasional. Beberapa dosen IAIN Walisongo telah memberikan kontribusi yang berupa karya akademik maupun riset studi. Misalnya karya ilmiah yang berupa buku yang ditulis secara individu maupun kolektif dan tulisan-tulisan yang dimuat dalam jurnal dan media massa lainnya.

Tabel 1

\section{Daftar Penelitian Perbankan Syari'ah Staf Pengajar Program Studi Perbankan Syari'ah IAIN Walisongo Semarang}

\begin{tabular}{|c|c|c|c|}
\hline Tahun & Judul Penelitian & $\begin{array}{c}\text { Sumber } \\
\text { dan Jenis } \\
\text { Dana }\end{array}$ & $\begin{array}{l}\text { Jumlah } \\
\text { Dana* } \\
\text { (juta } \\
\text { rupiah) }\end{array}$ \\
\hline 2007 & $\begin{array}{l}\text { Implementasi prinsip syari'ah pada perbankan syari'ah di } \\
\text { kota Semarang }\end{array}$ & $\begin{array}{l}\text { PT. } \\
\text { Sendiri }\end{array}$ & 7,5 \\
\hline 2007 & $\begin{array}{l}\text { Analisis Hubungan Individual Rank Profesionalisme } \\
\text { Auditor Intern, Hasil Kerja Auditor Intern Dan Kinerja } \\
\text { Lembaga Keuangan Syari'ah (Studi Pada Baitul Mal Wat } \\
\text { Tamwil Kota Semarang) }\end{array}$ & $\begin{array}{l}\text { PT. } \\
\text { Sendiri }\end{array}$ & 7,5 \\
\hline 2007 & $\begin{array}{l}\text { Analisis Manajemen Resiko Pembiayaan Produk Murabahah } \\
\text { (Studi Kasus Pada BMT Tamziz dan BMT Marhamah } \\
\text { Wonosobo) }\end{array}$ & $\begin{array}{l}\text { PT. } \\
\text { Sendiri }\end{array}$ & 7,5 \\
\hline 2008 & $\begin{array}{l}\text { Pengaruh Dimensi Serqual Terhadap Kepuasan Nasabah } \\
\text { Bank Syari'ah (Studi Pada Antor Cabang Bank Syari,ah ) }\end{array}$ & $\begin{array}{l}\text { PT. } \\
\text { Sendiri }\end{array}$ & 8 \\
\hline 2008 & Etika Bisnis Dalam Praktek Mal Bisnis Muhammad & $\begin{array}{l}\text { PT. } \\
\text { Sendiri }\end{array}$ & 8 \\
\hline 2008 & $\begin{array}{l}\text { Faktor-faktor yang mempengaruhi keinginan migrasi } \\
\text { nasabah bank umum sayariah di kota semarang }\end{array}$ & DIPA fak & 3 \\
\hline 2009 & $\begin{array}{l}\text { Pengaruh strategi ekslusif terhadap kinerja pemasaran } \\
\text { lembaga keuangan syari'ah (studi kasus di bank arta surya } \\
\text { barokah Semarang dan Asad Alif Sukorejo Kendal Tahun } \\
\text { 2009) }\end{array}$ & $\begin{array}{l}\text { PT. } \\
\text { Sendiri }\end{array}$ & 10 \\
\hline 2009 & $\begin{array}{l}\text { Membangun Model Kemitraan Bank Syari'ah Dengan } \\
\text { Nasabah Melalui Atribut Produk Islam dan Kualitas } \\
\text { Pelayanan Dengan Pendekatan Syari'ah Marketing }\end{array}$ & Depag RI & 35 \\
\hline 2009 & $\begin{array}{l}\text { Analisis Independensi dan Profesionalisme Dewan } \\
\text { Pengawas Syari'ah Serta Pengaruhnya Terhadap Kinerja } \\
\text { Bank Perkreditan Rakyat Syari'ah Di Jawa Tengah }\end{array}$ & Depag RI & 35 \\
\hline 2010 & Pengaruh kinerja ATM terhadap loyalitas dan kepuasan & Depag RI & 35 \\
\hline
\end{tabular}




\begin{tabular}{|c|c|c|c|}
\hline & nasabah perbankan syari'ah di jawa tengah & - & \\
\hline 2010 & $\begin{array}{l}\text { Studi preferensi dan potensi masyarakat serta pengaruhnya } \\
\text { terghadap sikap penerimaan bank syari'ah di kota } \\
\text { Semarang }\end{array}$ & DIPA BLU & 7,5 \\
\hline 2011 & $\begin{array}{l}\text { Analisis perbandingan kinerja keuangan bank syari'ah } \\
\text { dengan menggunakan income statement approach dan } \\
\text { value added approach }\end{array}$ & DIPA Fak & 10 \\
\hline
\end{tabular}

Sumber : Borang Prodi EI Perbankan syari'ah IAIN, 2010.

Selain itu, Program Studi Perbankan Syari'ah IAIN Walisongo juga telah menjalin kerja sama dengan lembaga terkait. Kerjasama akademik dilakukan dengan lembaga keuangan syari'ah, Bank Indonesia, institusi sejawat dan personal yang dibutuhkan. Lembaga keuangan syari'ah yang menjadi mitra kerjasama program studi perbankan syari'ah IAIN Walisongo adalah Bank Syari'ah Mandiri (BSM) Cabang Semarang, BNI Syari'ah Cabang Semarang, BPRS Asad Alif Sukorejo Kendal, BPRS Artha Surya Barokah Semarang, BPRS Ben Salamah Abadi Purwodadi, BRPS Artha Mas Abadi Pati, BPRS PNM-Binama Semarang, BMT Walisongo Semarang, BMT Damar Semarang, BMT Binama Semarang, BMT Marhamah Wonosobo, BMT Tamziz Wonosobo, BMT Muhammadiyah Pekalongan, BMT Bina Umat Sejahtera Lasem, BMT Ben Takwa Godong Purwodadi, BMT Hudatama Semarang, BMT Bina Insani Ungaran, dan PT Takaful Cabang Semarang. Selain lembaga keuangan syari'ah, kerja sama juga dilakukan dengan lembaga-lembaga sosial yang intens berhubungan dengan masalah syari'ah, yaitu Masyarakat Ekonomi Syari'ah (MES) Kota Semarang. Berdasar beberapa lembaga yang melakukan kerja sama tersebut, hal ini merepresentasikan bentuk kepedulian IAIN Walisongo untuk ikut andil dalam akselerasi pertumbuhan perbankan syari'ah di Kota Semarang.

\section{Kebutuban Inovasi Produk dan Layanan}

Hal lain yang krusial untuk diperhatikan dalam upaya akselerasi pertumbuhan perbankan syari'ah pasca pengesahan UU Perbankan Syari'ah adalah mendorong agar pelayanan perbankan syari'ah berbasis teknologi maju tidak jauh tertinggal dari perbankan konvensional, sepanjang menjalankan usahanya melalui distribusi produk dan layanan yang sesuai dengan norma-norma syari'ah. 
Upaya ini dapat mengakselerasi rekrutmen pengguna jasa perbankan syari'ah, bukan hanya di tataran domestik namun juga manca negara.

Jadi, inovasi produk dan layanan perbankan syari'ah harus dapat dilakukan secara dinamis namun tetap berada dalam koridor syari'ah sejati. Hal ini dapat dilakukan secara konsisten, bila dalam proses inovasi, riset-riset yang dilakukan melibatkan lembaga-lembaga yang relatif steril dari kepentingan industri. Independensi dari pengaruh industri dengan segala dinamikanya mutlak diperlukan untuk menghindarkan rekomendasi inovasi produk dan layanan (berbasis hasil riset) yang memasuki wilayah yang meragukan ( grey area). Independensi semacam ini dapat ditemukan pada lembaga pendidikan tinggi yang memang bercirikan ilmiah-objektif. Dengan demikian, pelibatan lembaga perguruan tinggi, dalam hal ini IAIN Walisongo, dalam riset-riset pengembangan produk perbankan syari'ah niscaya dapat membantu Dewan Pengawas Syari'ah dan manajemen di bank-bank syari'ah nasional dalam mempertajam daya saing bank syari'ah melalui inovasi produk dan layanan tanpa melanggar demarkasi syari'ah.

\section{Kebutuhan Sumber Daya Insani Yang Kompeten}

Sumber daya insani (SDI) dan kultur merupakan elemen fundamental yang menjadi pilar eksistensi industri perbankan syari'ah, serta membedakannya dari perbankan konvensional. Penelitian yang dilakukan Labolatorium Program Studi Perbankan Syari'ah IAIN Walisongo serta program magang di seluruh bank syari'ah di Kota Semarang, misalnya, mengungkap betapa praktik perbankan syari'ah belum memberikan perbedaan kualitatif yang diharapkan oleh captive market-nya dibandingkan dengan perbankan konvensional. 


\section{Tabel 2}

\section{Kondisi Sumber Daya Insani Perbankan Syari'ah di Kota Semarang}

\begin{tabular}{|c|c|c|}
\hline Keterangan & Sumber Daya & Kondisi \\
\hline Dominasi lulusan sarjana pada & Latar Belakang & $18 \%$ SMU ,21 \% D 3 \\
\hline bank-bank syari'ah di Indonesia & Pendidikan Staf & $59 \%$ S $1,2 \%$ S 2 \\
\hline Belum ada lulusan lembaga & Kelompok & $10 \%$ Ilmu Syari'ah \\
\hline pendidikan ekonomi Islam & Keilmuan Staf & 90\% Ilmu Konvensional \\
\hline Kecenderungan pengaruh & Asal Karyawan & 20\% Fresh Graduate PT \\
\hline framework konvensional dalam & & 70\% Bank Konvensional \\
\hline $\begin{array}{l}\text { perkembangan bank-bank } \\
\text { syari'ah }\end{array}$ & & ank Syari'ah lain \\
\hline
\end{tabular}

Sumber: Data Primer yang diolah, 2011.

Selanjutnya, dicatat pula bahwa unit-unit pelayanan syari'ah terdepan miskin penguasaan filosofi produk dan kering akan kultur syari'ah, sehingga memberi kesan seakan SDI bank syari'ah hanyalah SDM bank konvensional yang berganti asesori. Nilai-nilai SDI yang amanah, fathonah, shiddiq, tabligh, istiqomah yang terintegrasi dalam konsep Good Corporate Governance belum dapat diklaim sebagai identitas utama mayoritas bank syari'ah nasional. Bila informasi pada Tabel 2 diamati secara seksama, situasi yang digambarkan tentang SDI bank syari'ah di atas dapat dipahami, meski tidak dapat diterima. Dari sisi keilmuan, latar belakang pendidikan para karyawan bank-bank syari'ah lebih didominasi oleh pemilik ilmu konvensional (90\%), dan sebagian direkrut dengan latar belakang pengalaman bekerja di bank-bank konvensional (70\%).

Berkenaan dengan hal ini, peran perguruan tinggi dalam mensuplai SDI dan masukan berbasis keilmuan untuk pengembangan perbankan syari'ah adalah keniscayaan. Dengan bertambahnya jumlah Bank Umum Syari'ah pada tahun 2010 menjadi 10 bank maka kebutuhan akan SDI yang kompeten pun meningkat. Fadjrijah (2009) memperkirakan kebutuhan SDI terkait dengan pertumbuhan perbankan syari'ah ini mencapai 25.000 orang. Zadjuli (2009) bahkan memprediksi bahwa kebutuhan SDI berkualifikasi D3 hingga S3 dalam kurun waktu 5 tahun ke depan mencapai 38.940 orang. 
Dalam rangka mengembangkan khasanah keilmuan mahasiswa serta memperkaya kapasitas intelektual mahasiswa, IAIN Walisongo melakukan kerja sama dengan instansi lain guna memberikan tambahan wacana akademik, yaitu Kajian Motivasi dengan Masyarakat Ekonomi Syari'ah, Aksi Damai Untuk Indonesia Bebas Riba dengan Forum Silaturahmi Studi Ekonomi Islam (FOSSEI) Semarang, Studi Banding Sistem Ekonomi Islam dan Perbankan Syari'ah ke beberapa perguruan tinggi lain, dan bermacam-macam aktivitas bentuk kegiatan ekstra (secondary school). Adapun kegiatan yang melibatkan partisipasi mahasiswa pada tingkat nasional adalah Olimpiade Syari'ah, Gebyar Muslimah dan Debat Contest.

\section{Kerjasama dengan Instansi Keuangan Syari'ah}

Selain berperan sebagai penyedia sumber daya alam yang berkompeten di bidang perbankan syari'ah, IAIN Walisongo juga telah melakukan kerjasama dengan perbankan-perbankan syari'ah yang ada di Semarang yaitu dengan Bank Syari'ah Mandiri Cabang Semarang, BNI Syari'ah Cabang Semarang, Bank Muamalat Indonesia, dan beberapa BPRS dan BMT yang telah disebutkan pada bagian sebelumnya.

Bentuk kerjasama dengan Bank Muammalat Indonesia itu dapat dilihat dalam bentuk nota kesepahaman (MoU) dengan Bank Muamalat Indonesia bahwa IAIN Walisongo telah menyelenggarakan pendidikan Program Studi Perbankan Syari'ah. Kerjasama ini merupakan upaya bersama para pihak untuk mengembangkan berbagai aspek dalam bidang pendidikan dan pengembangan ekonomi Islam.

Kerjasama ini juga terjadi karena adanya kesamaan visi antara IAIN Walisongo dengan Bank Syari'ah Mandiri cabang Semarang karena sama-sama ingin mensosialisasikan dan mengembangkan sistem ekonomi Islam di Semarang. Perjanjian ini juga merupakan upaya bersama para pihak untuk mengembangkan berbagai aspek dalam bidang pendidikan dan pengembangan ekonomi Islam.

Adapun ruang lingkup yang terdapat dalam isi kerjasama dengan Bank syari'ah Mandiri cabang Semarang adalah melakukan pengembangan dan perencanaan pendidikan Program Studi 
Perbankan Syari'ah IAIN Walisongo, memberikan bantuan penyediaan tenaga pengajar, memberikan kesempatan kepada tenaga pengajar pihak IAIN Walisongo untuk mengikuti pelatihan yang diadakan oleh Bank Syari'ah Mandiri, memberikan kesempatan magang kepada mahasiswa semester akhir Program Studi Perbankan Syari'ah IAIN Walisongo sesuai dengan ketentuan yang ada pada Bank Syari'ah Mandiri cabang Semarang, serta memberikan kesempatan kepada lulusan jurusan Program Studi IAIN Walisongo untuk mengajukan permohonan sebagai karyawan Bank Syari'ah Mandiri sesuai dengan ketentuan penerimaan karyawan Bank Syari'ah Mandiri. Demikian pula Pada Bank Mega Syari'ah Semarang

\section{Tabel 3}

\section{Bentuk Kerja Sama dengan Instansi Lembaga Keuangan Syari'ah}

\begin{tabular}{|c|c|c|c|c|c|}
\hline \multirow[t]{2}{*}{ No. } & \multirow[t]{2}{*}{ Nama Instansi } & \multirow{2}{*}{$\underset{\text { Kegiatan }}{\text { Jenis }}$} & \multicolumn{2}{|c|}{$\begin{array}{c}\text { Kurun Waktu } \\
\text { Kerjasama }\end{array}$} & \multirow[t]{2}{*}{ Manfaat yang Telah Diperoleh } \\
\hline & & & Mulai & Berakhir & \\
\hline 1 & $\begin{array}{l}\text { Bank Indonesia } \\
\text { Semarang }\end{array}$ & Pendidikan & 2000 & Sekarang & $\begin{array}{l}\text { Peningkatan kualitas pembelajaran, } \\
\text { akses perpustakaan, magang } \\
\text { mahasiswa }\end{array}$ \\
\hline 2 & $\begin{array}{l}\text { Bank Muamalat } \\
\text { Indonesia }\end{array}$ & $\begin{array}{l}\text { Pengabdian } \\
\text { kepada Masyarakat }\end{array}$ & 2002 & & $\begin{array}{l}\text { Sosialisasi Perbankan Syari'ah, } \\
\text { magang mahasiswa }\end{array}$ \\
\hline 3 & BNI Syari'ah & Pendidikan & 2002 & Sekarang & Peningkatan kualitas pembelajaran \\
\hline 4 & $\begin{array}{l}\text { Bank Rakyat } \\
\text { Indonesia } \\
\text { Syari'ah }\end{array}$ & $\begin{array}{l}\text { Pengabdian } \\
\text { kepada Masyarakat }\end{array}$ & 2004 & & $\begin{array}{l}\text { Magang mahasiswaa perbankan } \\
\text { Syari'ah, }\end{array}$ \\
\hline 5 & $\begin{array}{l}\text { Bank BTN } \\
\text { Syari'ah }\end{array}$ & Pendidikan & 2007 & Sekarang & $\begin{array}{l}\text { Peningkatan kualitas pembelajaran, } \\
\text { magang }\end{array}$ \\
\hline 6 & $\begin{array}{l}\text { Bank Syari'ah } \\
\text { mandiri }\end{array}$ & $\begin{array}{l}\text { Pengabdian } \\
\text { kepada Masyarakat }\end{array}$ & 2009 & Sekarang & $\begin{array}{l}\text { Sosialisasi Perbankan Syari'ah, } \\
\text { Magang }\end{array}$ \\
\hline 7 & $\begin{array}{l}\text { BPRS Ben } \\
\text { salkamah } \\
\text { Purwodadi }\end{array}$ & $\begin{array}{l}\text { Pengabdian } \\
\text { kepada Masyarakat }\end{array}$ & 2004 & Sekarang & $\begin{array}{l}\text { Peningkatan kualitas pembelajaran, } \\
\text { magang }\end{array}$ \\
\hline 8 & $\begin{array}{l}\text { BPRS Artha Mas } \\
\text { Abadi Pati }\end{array}$ & $\begin{array}{l}\text { Pengabdian } \\
\text { kepada Masyarakat }\end{array}$ & 2004 & Sekarang & $\begin{array}{l}\text { Peningkatan kualitas pembelajaran, } \\
\text { magang }\end{array}$ \\
\hline 9 & $\begin{array}{l}\text { BPRS Suriyah } \\
\text { Semarang }\end{array}$ & $\begin{array}{l}\text { Pengabdian } \\
\text { kepada Masyarakat }\end{array}$ & 2004 & Sekarang & $\begin{array}{l}\text { Peningkatan kualitas pembelajaran, } \\
\text { magang }\end{array}$ \\
\hline 10 & $\begin{array}{l}\text { BPRS BInama } \\
\text { Semarang }\end{array}$ & $\begin{array}{l}\text { Pengabdian } \\
\text { kepada Masyarakat }\end{array}$ & 2004 & Sekarang & $\begin{array}{l}\text { Peningkatan kualitas pembelajaran, } \\
\text { magang }\end{array}$ \\
\hline 11 & $\begin{array}{l}\text { BMT Walisongo } \\
\text { Semarang }\end{array}$ & $\begin{array}{l}\text { Pengabdian } \\
\text { kepada Masyarakat }\end{array}$ & 2004 & Sekarang & $\begin{array}{l}\text { Peningkatan kualitas pembelajaran, } \\
\text { magang }\end{array}$ \\
\hline 12 & $\begin{array}{l}\text { BMT Damar } \\
\text { Semarang }\end{array}$ & $\begin{array}{l}\text { Pengabdian } \\
\text { kepada Masyarakat }\end{array}$ & 2004 & Sekarang & $\begin{array}{l}\text { Peningkatan kualitas pembelajaran, } \\
\text { magang }\end{array}$ \\
\hline 13 & $\begin{array}{l}\text { BPRS ARtha } \\
\text { Amanah }\end{array}$ & $\begin{array}{l}\text { Pengabdiaan } \\
\text { kepada masyarakat }\end{array}$ & 2007 & Sekarang & $\begin{array}{l}\text { Peningkatan kualitas pembelajaran, } \\
\text { magang }\end{array}$ \\
\hline 14 & $\begin{array}{l}\text { BPRS Artha } \\
\text { Surya Barokah }\end{array}$ & Pendidikan & 2007 & Sekarang & Peningkatan kualitas pembelajaran \\
\hline 15 & BMT Sy Bus & Pendidikan & 2007 & Sekarang & Peningkatan kualitas pembelajaran \\
\hline 16 & $\begin{array}{l}\text { BMT Fajar Mulia } \\
\text { Ungaran }\end{array}$ & $\begin{array}{l}\text { Pengabdiaan } \\
\text { kepada masyarakat }\end{array}$ & 2007 & Sekarang & $\begin{array}{l}\text { Peningkatan kualitas pembelajaran, } \\
\text { magang }\end{array}$ \\
\hline
\end{tabular}




\begin{tabular}{|c|c|c|c|c|c|}
\hline 17 & $\begin{array}{l}\text { BMT Binama } \\
\text { Semarang }\end{array}$ & $\begin{array}{l}\text { Pengabdiaan } \\
\text { kepada masyarakat }\end{array}$ & 2007 & Sekarang & $\begin{array}{l}\text { Peningkatan kualitas pembelajaran, } \\
\text { magang }\end{array}$ \\
\hline 18 & $\begin{array}{l}\text { BPRS Asad Alif } \\
\text { Sukorejo }\end{array}$ & $\begin{array}{l}\text { Pengabdiaan } \\
\text { kepada masyarakat }\end{array}$ & 2007 & Sekarang & $\begin{array}{l}\text { Peningkatan kualitas pembelajaran, } \\
\text { magang }\end{array}$ \\
\hline 19 & $\begin{array}{l}\text { BMT Hudatama } \\
\text { Semarang }\end{array}$ & $\begin{array}{l}\text { Pengabdiaan } \\
\text { kepada masyarakat }\end{array}$ & 2007 & Sekarang & $\begin{array}{l}\text { Peningkatan kualitas pembelajaran, } \\
\text { magang }\end{array}$ \\
\hline 20 & $\begin{array}{l}\text { BMT BIna Insani } \\
\text { Ungaran }\end{array}$ & $\begin{array}{l}\text { Pengabdiaan } \\
\text { kepada masyarakat }\end{array}$ & 2007 & Sekarang & $\begin{array}{l}\text { Peningkatan kualitas pembelajaran, } \\
\text { magang }\end{array}$ \\
\hline 21 & $\begin{array}{l}\text { BMT Tamzis } \\
\text { Wonosobo }\end{array}$ & $\begin{array}{l}\text { Pengabdiaan } \\
\text { kepada masyarakat }\end{array}$ & 2007 & Sekarang & $\begin{array}{l}\text { Peningkatan kualitas pembelajaran, } \\
\text { magang }\end{array}$ \\
\hline 22 & $\begin{array}{l}\text { BMT Marhamah } \\
\text { wonosobo }\end{array}$ & $\begin{array}{l}\text { Pengabdiaan } \\
\text { kepada masyarakat }\end{array}$ & 2007 & Sekarang & $\begin{array}{l}\text { Peningkatan kualitas pembelajaran, } \\
\text { magang }\end{array}$ \\
\hline 23 & BMT Salsabil & $\begin{array}{l}\text { Pengabdiaan } \\
\text { kepada masyarakat }\end{array}$ & 2007 & Sekarang & $\begin{array}{l}\text { Peningkatan kualitas pembelajaran, } \\
\text { magang }\end{array}$ \\
\hline 24 & $\begin{array}{l}\text { BMT Maslkah } \\
\text { ummah }\end{array}$ & $\begin{array}{l}\text { Pengabdiaan } \\
\text { kepada masyarakat }\end{array}$ & 2007 & Sekarang & $\begin{array}{l}\text { Peningkatan kualitas pembelajaran, } \\
\text { magang }\end{array}$ \\
\hline 25 & BSM Semarang & kerjasama & 2011 & Sekarang & Rekruitmen Tenaga kerja \\
\hline 26 & $\begin{array}{l}\text { Bank Mega } \\
\text { Syari'ah }\end{array}$ & kerjasama & 2011 & Sekarang & Rekruitm,en Tenaga Kerja \\
\hline
\end{tabular}

Sumber : Borang Prodi Perbankan IAIN Walisongo Semarang, 2010.

\section{Peran Serta Menyediakan Sumber Daya Manusia Di Bidang Perbankan Syari'ah}

Lembaga keuangan syari'ah yang terus berkembang membutuhkan jumlah SDM yang cukup banyak dan berkualitas. Kini banyak lembaga pendidikan tingi berusaha untuk memenuhi kebutuhan pasar tersebut. IAIN Walisongo sebagai salah satu lembaga pendidikan tinggi di Indonesia telah berperan sebagai penyedia sumber daya yang kompeten di bidang ekonomi syari'ah yaitu dengan dibukanya Pogram Studi Perbankan Syari'ah oleh Dirjen Pembinaan Kelembagaan Agama Islam Departemen Agama Republik Indonesia, pada tanggal 27 Desember 2001 No. SK Ijin Penyelenggaraan: E/299/2001.

Agar terjadi link and match dengan kebutuhan industri keuangan syari'ah, Program Studi Perbankan Syari'ah akan mempererat kerjasama dengan praktisi lembaga keuangan syari'ah, dalam bentuk pemberian materi kuliah oleh praktisi keuangan syari'ah dan membuka kesempatan magang lebih besar bagi mahasiswa. Untuk link and match dengan industri kurikulum pun juga dibuat bersama dengan asosiasi lembaga keuangan syari'ah dan para praktisi.

Menurut Chotim Zaini Asshidiqi (Manajer BPRS/Direktur Dinar-Dirham Group Surakarta), pegawai-pegawai yang bekerja 
pada perbankan-perbankan syari'ah yang ada di Semarang saat ini masih berasal dari sarjana ekonomi konvensional, sehinga mereka perlu pendidikan tambahan untuk memahami sistem ekonomi islam khususnya sistem perbankan syari'ah. Saat ini perbankanperbankan syari'ah yang ada di Semarang berharap tersedia sarjanasarjana ekonomi Islam yang benar-benar berkompeten di bidang perbankan syari'ah agar perbankan syari'ah yang telah ada dapat bekembang lebih baik.

Ketua Program Studi Perbankan Syari'ah IAIN Walisongo menyatakan bahwa untuk mendukung peningkatan kualitas lulusan SDM perbankan syari'ah IAIN Walisongo, sejumlah fasilitas pun akan turut dikembangkan seperti penyediaan laboratorium syari'ah, labolatorium bank syari'ah, dan beberapa fasilitas lain. Sedangkan dalam masa mendatang, perencanaan pengembangan perbankan syari'ah dapat dilakukan dengan cara penambahan fasilitas seperti ATM, Debit card, on-line, m-banking dan sebagainya, penambahan jumlah dan kantor cabang, peningkatan produk, mensosialisasikan perbankan syari'ah.

Untuk mendorong dan memenuhi kebutuhan SDM berkualitas tersebut, IAIN Walisongo melaksanakan berbagai program dalam rangka peningkatan kompetensi SDM perbankan syari'ah yang secara garis besar terdiri atas; Pertama, Pendidikan Dasar Perbankan Syari'ah (PDPS). Pendidikan Dasar Perbankan Syari'ah merupakan mata kuliah rutin yang diberikan kepada mahasiswa Program Studi Perbankan Syari'ah. Mata kuliah ini diberikan kepada mahasiswa melalui kerjasama dengan Bank Indonesia dalam bentuk pemberian materi kuliah oleh pakar perbankan dari Bank Indonesia. Materi dalam Program PDPS meliputi materi kebijakan, ketentuan, konsep dan prinsip dasar mengenai ekonomi dan perbankan syari'ah, dan akuntansi perbankan syari'ah. Kedua, Training Of Trainers (TOT). Sejalan dengan pelaksanaan PDPS, TOT juga merupakan program yang dilaksanakan IAIN Walisongo dalam rangka sosialisasi dan meningkatkan jumlah tenaga serta kualitas staf pengajar perbankan syari'ah. Program tersebut ditujukan bagi kalangan akademisi yaitu dosen Perbankan Syari'ah. 


\section{Perbankan Islam Peran IAIN Walisongo Dalam Masyarakat}

Bentuk peran serta IAIN Walisongo yang lain ialah dengan ikut serta menjadi peserta expo perbankan syari'ah dalam "Jateng Syari'ah Expo" tahun 2008 yang diadakan di Masjid Agung Jawa Tengah (MAJT). Jateng Syari'ah Expo ini Terselenggara berkat kerjasama antara Program Studi Perbankan Syari'ah dengan Masyarakat Ekonomi Syari'ah (MES) Kota Semarang. Kegiatan ini bertujuan untuk mensosialisasikan perbankan syari'ah di linkungan Kota Semarang. Manfaat yang dirasakan oleh perbankan syari'ah sendiri yaitu membantu tersosialisasinya perbankan syari'ah ke tengah masyarakat, di samping itu juga agar mahasiswa yang sudah mengenal teori tentang perbankan syari'ah dapat lebih memahami dengan melihat langsung.

Bentuk lain dari kegiatan sosialisasi yang dilakukan IAIN Walisongo adalah melakukan kegiatan pengabdian kepada masyarakat. Di mana terdapat beberapa staf pengajar IAIN Walisongo yang telah melakukan pengabdian langsung kepada masyarakat, dalam konteks ekonomi Islam atau pun perbankan syari'ah, seperti dalam table di bawah ini;

\section{Tabel 4}

\section{Daftar Pengabdian Kepada Masyarakat dalam Bidang Perbankan Syari'ah}

\begin{tabular}{clcc}
\hline Tahun & $\begin{array}{l}\text { Judul Kegiatan Pelayanan/Pengabdian kepada } \\
\text { Masyarakat }\end{array}$ & $\begin{array}{c}\text { Sumber dan } \\
\text { Jenis Dana }\end{array}$ & $\begin{array}{c}\text { Jumah } \\
\text { Dana } \\
\text { (juta } \\
\text { rupiah) }\end{array}$ \\
\hline \multirow{2}{*}{2007} & $\begin{array}{l}\text { Sosialisasai ekonomi syari'ah } \\
\text { Workshop pengembangan kurikulum Ekonomi } \\
\text { Islam dalam era globalisasi }\end{array}$ & MA / Hibah & 100 \\
& $\begin{array}{l}\text { Seminar peranan pasar modal syari'ah } \\
\text { Workshop pengembangan Program Studi Ekonomi }\end{array}$ & DIPA - IAIN & 25 \\
Islam di PTAI & DIPA - IAIN & 25 \\
$\begin{array}{l}\text { Seminar prospek seminar industri keuangan syari'ah } \\
\text { di Indonesia }\end{array}$ & DIPA - IAIN & 25 \\
$\begin{array}{l}\text { Seminar perbankkan syari'ah pasca UU NO. 21 Th } \\
\text { 2008 }\end{array}$ & DIPA - BLU & 25 \\
$\begin{array}{l}\text { Seminar pasar modal } \\
\text { Seminar nasional SDM ekonomi syari'ah }\end{array}$ & DIPA - IAIN & 25 \\
\hline
\end{tabular}

Sumber : Borang Prodi EI/ Perbankan Syari'ah IAIN Walisongo, 2010.

IAIN Walisongo telah melakukan kerjasama dengan Bank Muamalat (BMT) meskipun masih dalam lingkup yang kecil. Bentuk 
kerjasama ini adalah pembentukan Koperasi Jasa Keuangan Syari'ah (KJKS) BMT Walisong IAIN Walisongo Tahun 1999. Adapun produk yang dipakai ialah fungsi intermediasi.

Para anggota BMT Walisongo yang terdiri dari civitas akademika IAIN Walisongo serta masyarakat eksternal yang membutuhkan dana dapat meminjam ke BMT Walisongo. Adapun prosedur peminjamannya ialah anggota koperasi yang membutuhkan dana mengisi formulir permohonan yang telah disediakan oleh BMT Walisongo, selanjutnya anggota koperasi membawa formulir permohonan yang telah ditanda tangani dan disetujui oleh pengurus koperasi ke Bank Muamalat untuk di proses lebih lanjut. Selanjutnya bank akan melakukan prosedur pemberian pinjaman yang telah ditentukan. Setelah dana dapat dicairkan, nasabah yang merupakan anggota BMT Walisongo harus datang langsung ke BMT untuk mengambil dananya. Namun sebelumnya nasabah harus menjadi anggota terlebih dahulu di BMT Walisongo.

Saat ini peran IAIN Walisongo dalam mendorong masyarakat menjadi nasabah pada perbankan Islam terlihat jelas, minimal mengajak masyarakat dan civitas akademika IAIN Walisongo menjadi nasabah pendanaan pada perbankan syari'ah yang ada di IAIN Walisongo.

\section{Tabel 5 \\ Peran Perguruan Tinggi dalam Pengembangan Perbankan Syari'ah}

\begin{tabular}{ll}
\hline \multicolumn{1}{c}{ Tri Darma } & \multicolumn{1}{c}{ Kegiatan } \\
\hline \multirow{2}{*}{ Pengajaran } & $\begin{array}{l}\text { Penyusunan Kurikulum inti ilmu-ilmu terkait } \\
\text { pengembangan Lembaga Keuangan Syari'ah (seperti } \\
\text { Manajemen Syari'ah, Akuntansi Syari'ah, Ekonomi Syari'ah, } \\
\text { dsb) }\end{array}$ \\
& $\begin{array}{l}\text { Peningkatan staf pengajar berlatar belakang ilmu-ilmu } \\
\text { terkait pengembangan Lembaga Keuangan Syari'ah }\end{array}$ \\
& $\begin{array}{l}\text { Kolaborasi riset dengan industri regulator di bidang } \\
\text { keuangan dan perbankan syari'ah untuk up dated regulasi } \\
\text { dan kebutuhan industri }\end{array}$ \\
Penelitian & $\begin{array}{l}\text { Pembentukan Lembaga Riset, termasuk Forum Riset dan } \\
\text { Institusi Jurnal Riset guna melakukan improvisasi dan } \\
\text { pengujian empiris bidang pengembangan perbankan } \\
\text { syari'ah. }\end{array}$ \\
\hline
\end{tabular}




\begin{tabular}{ll}
\hline & Akselerasi sosialisasi produk dan layanan lembaga \\
Pengabdian & $\begin{array}{l}\text { keuangan syari'ah } \\
\text { pada }\end{array}$ - $\begin{array}{l}\text { Edukasi publik tentang perkembangan ekonomi dan } \\
\text { basyarakat yang terkait dengan kegiatan lembaga keuangan } \\
\text { syariah }\end{array}$ \\
\hline
\end{tabular}

Dari tabel di atas memperlihatkan beberapa gagasan terkait yang perlu diinisiasi dan diakselerasi oleh lembaga-lembaga perguruan tinggi termasuk IAIN Walisongo untuk mengisi peluang tersebut. Gagasan-gagasan di atas perlu segera direalisasikan agar perbankan syari'ah nasional tidak kehilangan momentum dalam kompetisi perbankan syari'ah regional dan global. Namun demikian, kita semua harus memonitor dan mengingatkan agar ikhtiar yang digagas di atas tidak menciptakan pertumbuhan perbankan syari'ah nasional yang semu, yaitu berbasis konsumsi dan meminggirkan usaha riil, serta kurang berdampak bagi kemaslahatan publik.

\section{Kesimpulan}

Dari hasil penelitian di atas dapat ditarik kesimpulan bahwa IAIN Walisongo Semarang telah berperan serta dalam mendorong perbankan syari'ah di Semarang. Bentuk- bentuk peran serta itu adalah sebagai berikut; Permasalahan urgensi aturan-aturan dan konsep derivasi pengembangan perbankan syari'ah, sosialisasi, dan kompetensi sumber daya mausia, serta pembinaan dan pendampingan terhadap nasabah pembiyaan. Keterlibatan sosialisasi perbankan Syari'ah pada masyarakat, dan kerjasama dengan instansi keuangan syari'ah, dan keterlibatan IAIN Walisongo terhadap perbankan syari'ah dalam bidang pembiayaan, dan mendorong masyarakat menjadi nasabah perbankan syari'ah.

Selain IAIN Walisongo Semarang peran ini juga dapat dilakukan oleh lembaga-lembaga pendidikan tinggi di Indonesia untuk mengisi kebutuhan industri perbankan syari'ah nasional melalui kegiatan Tri Darma PT-nya, terutama untuk membantu industri tersebut dalam mengentaskan masalah-masalah derivasi dan translasi aturan Perbankan Syari'ah nasional, produk dan layanan, sosialisasi, dan kompetensi sumber daya insani. 


\section{Daftar Pustaka}

Ahmad, Abu Umar Faruq and Hassan, M. Kabir. 2007. Regulation and Performance of Islamic Banking in Bangladesh. Thunderbird International Business Review. 49, 2007.

Ahmad, Faruq. Hassan, Kabir. Riba and Islamic Banking, Journal of Islamic Economics, Banking and Finance, University of New Orleans.

Antonio, Syafi'i, M. 2001. Bank Syari'ah dari Teori ke Praktek. Jakarta: Gema Insani Press.

Bank Indonesia. 2002. Cetak Biru Pengembangan Perbankan Syari'ah Indonesia, Jakarta.

Bank Indonesia. 2007. Makalah Perkembangan Perbankan Syari'ah.

Bank Indonesia. 2009. Direktori Perbankan Indonesia.

Baraba, Achmad. Prinsip Dasar Operasional Perbankan Syari'ah, Paper, Mimeo.

Bjorklund, Irene. Lundstrom Lisbeth. 2004. Islamic Banking: An Alternatif System, Paper, Kristian Stad University.

Chapra, M. Umer. 2001. Masa Depan Ilmu Ekonomi Sebuab Tinjauan Islam. Jakarta: Gema Insani Press.

Dhumale and Sapcanin. 2000. An Application of Islamic Banking to Microfinance, UNDP \& World Bank Technical Note, 2000.

Direktorat Perbankan Syari'ah. 2008. "Statistik Perbankan Syari'ab". Bank Indonesia.

Hilman, Iman. 2003. Perbankan Syari'ah Masa Depan. Jakarta: Senapelan Abadi Publishing.

Prasetyoningrum, Ari Kristin, 2010. Pengarub Dimensi-Dimensi Serqual terhadap Kepuasan Nasabah Bank Syari'ah Cabang kota Semarang. Jurnal Ekonomika, Vol. I, Edisi 1, 2010.

Saleem, Shahid. 2007. Role of Islamic Banks in Economic Development, available at ssrn.com/abstract $=989055$. Lahore: University of Punjab.

Soemardjan, Selo dan Soelaiman Soemardi. 1964. Sosiologi Suatu Pengantar. Jakarta: Universitas Indonesia. 
Soekanto, Soerjono. 1982. Sosiologi Suatu Pengantar. Jakarta: PT. Rajawali.

Sukarmadji. 2009. Beberapa Konsep Pemikiran Pengembangan

Peran Perbankan Syari'ah. Seminar Nasional Ekonomi Syari'ah. Maret 2009.

Veithzal Rivai, et .al. 2007. Bank and Financial Institution Management, Jakarta: Raja Grafindo Persada, Jakarta.

Yafie, Ali. 2003. Ekonomi Islam Dalam Sorotan. Jakarta : Pustaka Amanah.

Zadjuli. 2009. Sistem Pendidikan dan Ekonomi Islam Sebagai Solusi Meniadakan Kemiskinan dan Ketidakadilan dalam rangka Membangun Masyarakat Madani secara Kaffah. Seminar Nasional Ekonomi Syari'ah. UNPAD. 